УДК 346.34

DOI https://doi.org/10.32849/2663-5313/2021.5.07

\title{
Ігор Товкун,
}

канд. юрид. наук, дочент,

дочент кафедри господарського права

Начіонального юридичного університету імені Ярослава Мудрого

Дмитро Зал,

студент міжнародно-правового факультету

Начіонального юридичного університету імені Ярослава Мудрого

\section{УКЛАДЕННЯ ДОГОВОРУ ПОСТАВКИ У СПРОЩЕНІЙ ФОРМІ: НА МАТЕРІАЛАХ СУДОВОЇ ПРАКТИКИ}

У статті розглянуто деякі проблеми укладення договору поставки у спрошеній формі, проаналізовано актуальну судову практику судів вищих інстаниій щодо вказаного питання, акиентовано увагу на деяких проблемах реалізації сторонами договору поставки права на вступ у договірні відносини у спрощеній спосіб.

Принцип диспозитивності, який є наскрізним для цивільного та господарського права, робить договір головним регулятором взаємовідносин, що виникають між суб'єктами господарювання. Отже, дослідження договору як базису організачії і виникнення господарських правовідносин лишається актуальним питанням у сучасному правозастосуванні. Своєю чергою, одним із найголовніших та найпопулярніших договорів у сфері економіки та торгівлі лишається договір поставки. Економічна система жодної з країн не може існувати без експорту та імпорту товарів через митний кордон; аналогічна ситуація $і$ з переміщенням товарів у межах території країни, яке здебільшого лежить у межах договірних поставок товару, тому договір поставки у цьому питанні відіграє ключову роль.

Під час вступу в договірні відносини у формі укладання спрощеного договору поставки суб'єкт господарювання самостійно несе додаткові ризики його невиконання чи неналежного виконання іншою стороною. 3 огляду на наведене, аналіз судової практики щодо договорів спрощеної поставки дасть змогу передусім окреслити низку проблем, з якими зустрічаються контрагенти під час укладення таких договорів на практииі, а до того ж надасть базис для формування підходів для вирішення таких проблем, що повинно стати предметом подальших наукових розробок у наведеній сфері.

Доказування укладення договору поставки у спрощеній формі можна виділити в окрему сферу проблематики. Дискусій стосовно иього не вгасають, проте виші судові інстаниї̈ виклали своє розуміння меж, обсягу і засобів доказування, перерахувавши їх та дали очінку доводам сторін у судових рішеннях.

До того ж судова практика судів вищих інстаниій досить якісно тлумачить норми чинного законодавства, що дає змогу зробити обгрунтовані висновки щодо вибору того чи іншого способу захисту порушених прав суб'єкта господарювання та вказати на недосконалість нормативно-правового забезпечення спрощених поставок в Украӥні.

Ключові слова: спрощена поставка, спрощена форма договору, контрагент, договірні відносини, судова практика, проблеми доказування.

Постановка проблеми. Неабиякий попит договорів поставки у сучасному суспільстві породжує чимало спорів, які є предметом регулювання договірного права і вирішуються, як правило, у судовому порядку. Хоча законом і передбачена процедура досудового врегулювання спору, а державою було запроваджено інститут обов'язкового фінансового моніторингу контрагентів, останні не завжди виявляються добросовісними, надійними та такими, що готові вирішувати суперечки й розбіжності в позасудовому порядку. У зв'язку з наведеним украй доречно окрес- лити проблеми нормотворчої та правозастосовної практики, зокрема щодо укладання договору поставки у спрощеній формі.

Проблематика договірних поставок завжди привертала увагу чималої кількості науковців. Такими науковцями, як О.В. Бондар, К.Ю. Біла, В.О. Годун, О.Ю. Казакова, А.А. Чеботаєва, розкрито питання щодо можливих шляхів удосконалення договору поставки в контексті дуалізму приватного права, особливості його правового регулювання, відповідальність за його порушення, розмежування 3 договором купівлі-продажу 
тощо. Разом із тим на разі відсутні будь-які системні монографічні дослідження щодо спрощеного способу укладення договору поставки, однак аналіз судової практики свідчить, що вказане питання у зв'язку з великою кількістю судових справ потребуе значної уваги з боку наукового кола, подальших досліджень та розробок у вказаній сфері.

Метою статті $\epsilon$ розкриття правової природи та змісту спрощеного договору поставки в контексті актуальної нормотворчої та правозастосовної практики. Для реалізації мети дослідження необхідно виконати такі завдання: 1) визначити проблеми нормативного регулювання спрощеного договору поставки; 2) здійснити підбір та аналіз актуальної судової практики судів вищих інстанцій, що стосується укладення договору поставки у спрощеній формі.

Виклад основного матеріалу. Вибір контрагента під час укладення будь-якого договору потребує певної обачності від кожної зі сторін. Коли йдеться про укладення договору поставки, а тим більше у спрощеній формі, вимога щодо обачності набуває особливого значення. Отже, 3-поміж ризиків, який несе сам по собі договір поставки, за його спрощеної форми виникає необхідність доведення факту його укладання взагалі.

У контексті згаданих ризиків слушною є позиція К.Ю. Білої, яка наголошує на можливості виникнення між сторонами договору поставки суперечок щодо фактичної розумності витрат, що відшкодовуються стороною, розміру заборгованості, обсягу відповідальності кожної зі сторін та, нарешті, фактичної поставки товару [1, с. 20-21].

Не можемо не погодитися 3 позицією B.О. Годун, яка акцентує увагу на так званих «сірих зонах» нормативного регулювання поставки товару, зокрема недосконалості норм ГК України щодо предмета вказаного договору, строку якості товару, порядку укладання, умов виконання та обсягу відповідальності [2, с. 798]. Так, дійсно, чинне законодавство України не містить типового примірнику договору поставки. 3 одного боку, законодавець вирішив надати контрагентам можливість самостійно вибирати пункти договору, що у цілому $€$ складовою частиною принципу свободи договору, який є основоположним для відносин між суб'єктами господарювання; з іншого ж боку, такі широкі можливості часто призводять до спорів між сторонами та укладення договору у спрощеній формі, до якого сторони не готові, у зв’язку з недосконалим, місцями недостатнім нормативним регулюванням останнього.

У питанні укладення договорів поставки у спрощеній формі автори притримуються позиції щодо необхідності встановлення попередніх відносин між суб'єктами господарювання «на папері», тобто спрощеним поставкам повинно передувати укладення звичайного договору у письмовій формі з підписами сторін. Такий підхід дасть змогу вирішити низку проблем: по-перше, перевірити надійність контрагента; по-друге, гарантувати собі реальний договірний захист від неправомірних дій іншої сторони; по-трете, налагодити базу для подальших поставок у спрощеній формі, викликати впевненість щодо наявності потрібного товару в розпорядженні продавця та готовності покупця такий товар прийняти. Вищенаведене є запорукою стійких та довготривалих відносин між суб'єктами господарювання. Лише після вказаних дій можливим є перехід до укладення договору у спрощеній формі.

Проте навіть підхід, який рекомендують використовувати автори під час укладення договорів поставки, не завжди є досконалим. У практиці існують випадки недобросовісного виконання сторонами договору спрощеної поставки його умов. Йдеться про випадки невиконання, що може виявлятися у бездіяльності постачальника щодо поставки товару чи неналежного виконання, наприклад невиконання покупцем обов'язку щодо попередньої оплати товару у відповідному розмірі тощо.

Коли йдеться про спрощену форму укладення договору поставки, слід розуміти, що договір усе ж таки має місце бути. Категорично не погоджуємося 3 позицією Е.Б. Казакової, А.А. Чеботаєвої, які вказують, що у разі порушення стороною договору спрощеної поставки кошти, отримані іншою стороною, можна повернути в порядку «неосновательного обогащения» (мовою оригіналу) [3]. Так зване «неосновательное обогащение», закріплене у ч. 1 ст. 1105 ЦК РФ [4], є аналогом безпідставно набутого майна, що в українському законодавстві врегульовано главою 83 ЦК України [5]. Такий підхід зарубіжних науковців, на наше переконання, $€$ помилковим, оскільки безпідставно набуте майно за своїм правовим режимом належить до майна, передумовою для набуття якого $€$ відсутність будь-яких правовідносин між суб'єктами господарювання, у тому числі договірних. Укладення сторонами договору поставки, хоча й у спрощеній формі, свідчить про те, що майно придбавалося/поставлялося стороною на відповідній правовій підставі - на підставі договору поставки.

Із приводу безпідставно набутого майна слушно висловився Касаційний господарський суд у складі Верховного Суду у Постанові у справі № 910/13271/18 від 06.02.2020. 
Так, судом було констатовано помилковість висновків судів попередніх інстанцій, якими до спірних правовідносин були застосовані положення ст. 1212 ЦК України. В обгрунтування своєї правової позиції суд указав, що для виникнення зобов'язань із безпідставного набуття чи збереження майна може відбуватися за наявності трьох умов, серед яких: 1) необхідність набуття чи збереження майна; 2) таке набуття або збереження обов'язково повинно відбуватися за рахунок іншої особи; 3) відсутність положень нормативних актів, правочинів чи інших підстав для набуття чи збереження майна. У вказаній Постанові суд додатково наголосив на звуженості застосування інституту безпідставного набуття чи збереження майна у договірних правовідносинах, указавши, що набуття стороною правочину майна за рахунок іншої сторони в межах договору не може вважатися безпідставним [6].

Указаний висновок щодо застосування ст. 1212 ЦК України повністю підтверджує позицію авторів щодо неможливості поширення її дії на спрощені договірні поставки.

Переходячи до інших проблем договірних поставок у спрощеній формі, доречно звернутися до питання доказування фактичної поставки товару в межах спрощеного договору поставки та, як наслідок, доведення факту виникнення договірних правовідносин між сторонами.

На практиці зустрічається чимала кількість випадків, коли зобов'язаною стороною заперечуються будь-які договірні відносини між управненою стороною. За вказаного виникає проблема щодо доведення добросовісним контрагентом виникнення правовідносин з іншою стороною, якою будь-які відносини заперечуються. Судова практика судів вищих інстанцій свідчить про непоодинокі випадки вищенаведеної ситуації.

Так, згідно з правовою позицією Касаційного господарського суду у складі Верховного Суду, викладеною у Постанові по справі № 904/3074/18 від 01.11.2019, факт передачі товару покупцю та набуття права власності на нього може бути підтверджений первинними обліковими документами у розумінні Закону України «Про бухгалтерський облік та фінансову звітність в Україні», зокрема видатковими накладними. Однак відповідні документи на підтвердження поставки відповідачем товару позивачу суду не надано [7].

У вказаному випадку судом, по суті, констатовано, що підтвердженням виникнення між сторонами договірних правовідносин можуть бути первинні бухгалтерські документи, тягар доказування виникнення договірних відносин покладається на сторони. із цього вбачається, що з метою доведення укладення договору поставки у спрощеній формі, обов'язковим є надання до суду відповідних переконливих доказів, які можуть свідчити про те, що сторони дійсно вступили у правовідносини.

Аналогічну позицію було викладено й у Постанові по справі № 910/13303/19 від 16.09.2020, де Верховний Суд дійшов до висновку, що суди попередніх інстанцій під час задоволення позовних вимог обгрунтовано виходили з того, заборгованість підтверджується видатковими накладними, які підписані та скріплені печатками сторін без зауважень та заперечень [8].

У Постанові Верховного Суду по справі № 922/1467/19 від 15.05.2020 Суд указав, що підписання покупцем видаткової накладної, яка є первинним обліковим документом у розумінні Закону України «Про бухгалтерський облік та фінансову звітність в Україні» і фіксує факт здійснення господарської операції та встановлення договірних відносин, $€$ підставою виникнення обов 'язку щодо здійснення розрахунків за отриманий товар [9].

Отже, 3 наведеного вбачається, що суди стають на бік контрагента, який звернувся за захистом своїх прав, виключно за умови подання останнім до суду доказів виникнення договірних відносин між сторонами; чи, навпаки, у разі звернення до суду покупця внаслідок відсутності доказів поставки товару. Указане можливе за умови, якщо покупець, наприклад, здійснив попередню оплату товару, але не отримав його від постачальника. У такому разі суд стає на бік покупця у зв'язку з відсутністю у матеріалах справи доказів прийняття товару за наявності доказів його попередньої оплати.

Хоча такий перелік доказів, які можуть підтверджувати поставку товару ніде не закріплений, доречно визнати, що первинні бухгалтерські документи, можуть бути чи не єдиними доказами укладення спрощеного договору. У зв'язку з наведеним доцільно вказати про необхідність закріплення у чинному господарському законодавстві переліку тих документів, якими може підтверджуватися спрощена договірна поставка.

Зазначене $є$ актуальним й з огляду на те, що далеко не всі бухгалтерські документи можуть підтверджувати господарські операції та, як наслідок, виникнення договірних правовідносин між сторонами.

Так, зокрема, у Постанові Верховного Суду по справі № 905/1198/17 від 19.04.2018 було зазначено, що акт звірки взаєморозрахунків у сфері бухгалтерського обліку та фінансової звітності виступає фіксуючим документом, який фіксує заборгованість, 
а в окремих випадках рух коштів у бухгалтерському обліку підприємства та носить інформаційній характер, зокрема підтверджує тотожність ведення бухгалтерського обліку господарських операцій обома контрагентами, а сам по собі акт звірки взаєморозрахунків не може бути належним доказом здійснення господарської операції (поставки, надання послуг тощо) [10].

Окрім того, у Постанові Верховного Суду по справі № 915/641/19 від 29.04.2020 колегія суддів звернула увагу на те, що рахунок на оплату за своєю правовою природою не $€$ первинним документом, а лише містить платіжні реквізити, на які необхідно здійснити оплату (переказати кошти як оплату) за надані послуги, тобто носить інформаційний характер [11].

Отже, необхідно вказати, що суди критично ставляться до наданих стороною доказів, які не є первинними бухгалтерськими документами в розумінні чинного законодавства України, у зв'язку наведеним останні не можуть покладатися в основу доказування поставки товару та виникнення договірних відносин. 3 огляду на викладене, вкрай доречно було б урегулювати ці питання на законодавчому рівні, закріпити у господарському законодавстві норму, що визначала б, якими документами може бути підтверджена поставка товару, а які носять суто інформаційний характер та не можуть бути враховані судом під час прийняття рішення по справі.

\section{Висновки}

3 урахуванням викладеного справедливо дійти висновку, що договір поставки лишається ключовим договором на ринку торговельно-економічних відносин. Законодавче регулювання поставок в Україні не $€$ досконалим, що вимагає від контрагентів певного обсягу розсудливості та передбачуваності настання відповідних ризиків. Договір поставки, який укладається у спрощеній формі, порівняно зі звичайним договором несе у собі додаткові ризики, що повинні бути враховані суб'єктами господарювання під час вступу у такі правовідносини.

Спрощена форма договору поставки відрізняється від звичайної насамперед тим, що за виникнення спору сторони змушені додатково доводити обставини його укладання та підтверджувати це належними доказами. Аналіз судової практики свідчить, що такими доказами можуть бути первинні бухгалтерські документи.
Водночас на законодавчому рівні відсутнє закріплення хоча б приблизного переліку документів, які можуть підтверджувати факт поставки товару, що викликає певні труднощі у правозастосовній діяльності і потребує уваги з боку законодавця.

\section{Список використаних джерел:}

1. Белая Е.Ю. Защита прав покупателей по договору поставки. Международный журнал гуманитарных и естественных наук. 2020. № 6-3(45). C. 20-22.

2. Годун В.О. Договір поставки в контексті дуалізуму приватного права: пропозиції щодо вдосконалення. Молодий вчений. 2018. № 11(2). C. 795-799.

3. Казакова Е.Б., Чеботаева А.А. Договор поставки: основные проблемы его применения. Наука. Общество. Государство. 2019. Т. 7. № 1(25). URL: https://esj.pnzgu.ru/ (дата звернення: 17.03.2021).

4. Гражданский кодекс Российской Федерации (часть вторая) от 26.01.1996 № 14-ФЗ (ред. от 09.03.2021). URL: http://www.consultant.ru/ document/cons_doc_LAW_9027/367c354171430 785e666d9ec50b84932 fe3f39е 8/ (дата звернення: 19.03.2021).

5. Цивільний кодекс України. Відомості Верховної Ради України. 2003. № 40. Ст. 356.

6. Постанова Касаційного господарського суду у складі Верховного Суду по справі № 910/13271/18 від 06.02.2020. URL: https://reyestr.court.gov.ua/Review/87426717 (дата звернення: 25.03.2021).

7. Постанова Касаційного господарського суду у складі Верховного Суду по справі № 904/3074/18 від 01.11.2019. URL: https://reyestr.court.gov.ua/Review/85711189 (дата звернення: 27.03.2021).

8. Постанова Касаційного господарського суду у складі Верховного Суду по справі № 910/13303/19 від 16.09.2020. URL: https://reyestr.court.gov.ua/Review/91622174 (дата звернення: 30.03.2021).

9. Постанова Касаційного господарського суду у складі Верховного Суду по справі № 922/1467/19 від 15.05.2020. URL: https://reyestr.court.gov.ua/Review/89321270 (дата звернення: 30.03.2021).

10. Постанова Касаційного господарського суду у складі Верховного Суду по справі № 905/1198/17 від 19.04.2018. URL: https://reyestr.court.gov.ua/Review/73564995 (дата звернення: 10.04.2021).

11. Постанова Касаційного господарського суду у складі Верховного Суду по справі № 915/641/19 від 29.04.2020. URL: https://reyestr.court.gov.ua/ Review/89008774 (дата звернення: 17.04.2021). 
Ihor Tovkun, Dmytro Zal. Conclusion of a supply agreement in a simplified form: a case study of court practice

The article considers some problems of concluding a supply contract in a simplified form, analyzes the current case law of higher courts on this issue, focuses on some problems of the parties to the supply contract the right to enter into a contractual relationship in a simplified manner.

The principle of dispositiveness, which is pervasive for civil and commercial law, makes the contract the main regulator of the relationship that arises between businesses. Therefore, the study of the contract as the basis of the organization and the emergence of economic relations remains a topical issue in modern law enforcement. In turn, one of the most important and popular contracts in the field of economy and trade is the supply contract. The economic system of any country can not exist without the export and import of goods across the customs border; the situation is similar with the movement of goods within the territory of the country, which is mostly within the contractual supply of goods, so the supply contract plays a key role in this matter.

When entering into a contractual relationship in the form of a simplified supply contract, the entity independently bears additional risks of non-performance or improper performance by the other party. In view of the above, the analysis of case law on simplified supply contracts will first of all outline a number of problems encountered by contractors in concluding such contracts in practice, and also provide a basis for developing approaches to address such problems, which should be the subject. further scientific developments in this field.

Proof of the conclusion of a supply contract in a simplified form can now be divided into a separate area of the issue. Discussions in this regard do not subside, but the higher courts have set out their understanding of the limits, scope and means of proof, listing them by assessing the arguments of the parties in court decisions.

In addition, the case law of higher courts interprets the current legislation quite well, which allows to make reasonable conclusions about the choice of one or another way to protect the violated rights of the business entity and point to the imperfections of regulatory support for simplified supplies in Ukraine.

Key words: supply contract, simplified form of contract, contractor, contractual relations, case law, problems of proof. 